\title{
Minangkabau Visual Identity Principle in Virtual World
}

\author{
Elda Franzia
}

\begin{abstract}
Minangkabau is one of ethnic community in Indonesia. Minangkabau people have certain value to follow while growing as modern society. Known as their culture to migrate outside their hometown, Minangkabau people also becoming active and exist in virtual world. In the cyber society, some of Minangkabau people imagining their ethnic self through their account's profile picture. This research aims to identify the principles hold by Minangkabau people as they declaring their ethnic self in virtual world. The declaration of their ethnicity in a non boundary world is how they imagining themselves in the real world. The approach of this research is cultural studies with virtual ethnography method. The data collected by virtual observation and documentation. The data analyzed by visual composition interpretation method and related to the ethnic value of Minangkabau people. The ethnic value believed by the Minangkabau people is how they identifying their ethnic self in virtual world. The research summarized in six principles of subjectivity and visual identity of Minangkabau ethnic people.
\end{abstract}

Index Terms—Ethnic, identity, Minangkabau, virtual.

\section{INTRODUCTION}

Indonesia is a diverse country. It has more than 300 ethnics groups spread around on 34 provinces and 13,677 islands in Indonesia. With a total area of 1,919,440 sq km (741,100 sq $\mathrm{mi})$, Indonesia is the fourth-largest Asian country after China, India, and Saudi Arabia [1]. The five principal islands are Sumatra, Java, Borneo (Kalimantan), Sulawesi, and Irian Jaya One of the ethnic groups is Minangkabau. Minangkabau ethnic is from West Sumatra and known as the fourth largest ethnic group in Indonesia. Minangkabau people have a tradition to leave their homeland in West Sumatra and go across the country and abroad to make a better living. From their agricultural tradition, Minangkabau people known for its dynamicity and living harmonically in their new land. This tradition called merantau or going away. Minangkabau ethnic also has a cultural belief. Based on the deep understanding for Islamic religion and communal tradition, they have a proverb "Dima bumi dipijak, di situ langik dijunjung". It means wherever they are, there is sky to honor. The sky also means the land and their cultural tradition of new land's community. It is also a representation of their attachment to community and family. Minangkabau ethnic people are known to flock around their ethnic people but also maintain good honorable relationship to others.

The fast growing of technology is a basis to the expanding of new land called virtual world. As a dynamic community,

Manuscript received March 12, 2018; revised June 12, 2018. This work was supported in part by Faculty of Art and Design, Trisakti University under research grant.

Elda Franzia is with the Faculty of Art and Design, Trisakti University, Kampus A, Jl. Kyai Tapa no. 1, Jakarta 11440, Indonesia (e-mail: eldafranzia@gmail.com, elda@trisakti.ac.id).
Minangkabau ethnic also spread to the virtual world. They are becoming active and exist in virtual world. The popularity of instant messenger application and social media increase the communication and interaction of Minangkabau ethnic people in virtual world. There are various groups of Minangkabau people in popular social media such as Facebook. The groups based on several backgrounds such as the mother line of family, hometown, historical approach, or chatting and social approach. Those groups use specific profile picture that can related visually to Minangkabau ethnic. Some of Minangkabau people also use visible characteristic of Minangkabau ethnic in their account's profile picture. These activity is the indication of Minangkabau ethnic people who imagining their ethnic self in virtual world. This research aims to identify the principles hold by Minangkabau people as they declaring their ethnic self in virtual world.

\section{METHODOLOGY}

This research approach is cultural study with the virtual ethnography method to understand the human tendency to build their self identity in virtual world. Cultural studies explore how self identity as subject, as they being. Virtual ethnography focused into the experience with the research society and the cultural process, not to the place [2]. Interaction with the research society is done through the online communication. Visual analysis method is use to analyze profile picture of Minangkabau ethnic people. The method is image composition interpretation [3]. Image is a combination and composition of visual elements. Composition formed by objects in image, colors, spatial organization, lighting, and expressive content. Colors include the color combination and nuance. Spatial organization is the view and visual tension in the image. Lighting includes the type of lighting in the image, and the expressive content is the expression showed by the image directly or indirectly.

The profile picture use as sample of this research is gathered with purposive sampling method. The sample required several criteria, which are (a) Contained Minangkabau ethnic characteristics, explicitly or implicitly (b) Showed various characteristics (c) Showed Minangkabau traditional culture (d) Had complexity in aesthetic or technological aspects (e) Had creativity and visual uniqueness.

\section{STUDY OF THE THEORY}

The development of technology and expanding of living spaces are factors that had effect the difference in traditional practice in everyday life of Minangkabau ethnic people. 


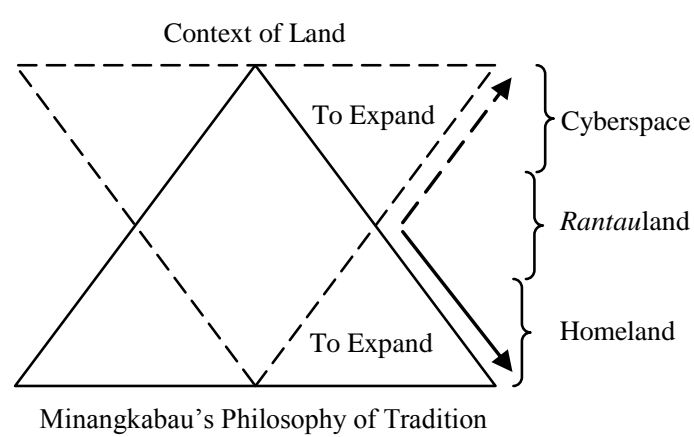

Fig. 1. Relation between land and minangkabau's philosophy of tradition.

The difference of Minangkabau's cultural and tradition practice has caused by the expanding of land and how it affected the person's life especially in their inner understanding of cultural values. Nature is the central life for Minangkabau ethnic people. Nature is considering as not just a place to birth and grow but also as the center of cosmic and life value. Minangkabau people are connected to the land where they live. The appreciation of life value has been given by nature also define how the Minangkabau people respect others in the place where they being. The philosophy is equality, as a personal self to others, and as a part of nature who need other creatures to life [4]. Wherever the Minangkabau people live, they must adapt to the local culture without losing their cultural identity. The relation between the land and the understanding and practice of Minangkabau's philosophy of tradition explained in Figure 1 above.

To explore and to adapt is the social philosophy of Minangkabau ethnic people. From homeland, the Minangkabau ethnic people spread in social and cultural way of life. Merantau, or the custom to immigrate, is considered as a way to search for a better life, not only for personal needs but also for their hometown. They leave their hometown to higher education or work for a period of time. Temporary immigration is becoming a cultural transmitter process. Minangkabau cultural value is being exchange with other cultural values [5]. Merantau is also intended to increase the knowledge, open mind, and the ability to adopt information for Minangkabau people. The knowledge through education also intended to increase intellectual openness and flexibility to develop the self-direction values. It changes the vision and sense of purpose of Minangkabau people to absorb modernization.

Cyberspace is the next step of merantau culture for Minangkabau ethnic people. In virtual world, the Minangkabau ethnic people appear in groups and individually as online self. Sherry Turkle says that online self is a second self, since computer became identity transformation media between self and machine, and relation between self and computer as machine is one on one [6]. Second self is on when the person online, and the real self is when the person offline. In virtual world, every person has a capability and freedom to create themselves as a representation of self in cyber interaction. This virtual interaction is a self definition and self invention. Therefore the virtual identity is not necessarily the same as real identity. It is an uncertainty [7].

As the representation of self in virtual world, profile picture is becoming a substantial part of personal identity in cyberspace. Profile picture is a communication medium from one account to another in online interaction. Profile picture is a potential representation in virtual world. It represents who we are and how we appear in virtual communication. It connects individual in their communication territory. In online communication, basic interaction change to virtual space and being. The self present, personal appearance, gesture, and communication move into the virtual representation [8]. Personal appearance includes the individual physical appearance such as skin color, face, gesture, hair style, fashion style, and make up. In profile picture as an image, face expression, gesture, and fashion style is a significant elements to visual communication.

\section{MinANGKABAU VisUal IDENTITY IN VIRTUAL WORLD}

The profile picture of Minangkabau visual identity in social media differs into two categories, (a) Displayed photograph of person, individual or collective, and (b) Displayed visual image with Minangkabau characteristic. Each category showed visual elements as their visual communication intentions. The profile picture that displayed photographs contained visual elements which are (a) expression, (b) gesture, (c) fashion style, (d) make up, (e) hair style, (f) accessories, (g) background, (h) fashion colors, (i) background colors, (k) layout, (1) visual weight, (m) focus, (n) camera view, (o) camera length, (p) space and lighting. On the other hand, the profile picture that displayed Minangkabau characteristic image contained visual elements which are (a) form, (b) line, (c) direction, (d) typography, (e) form colors, (f) background colors, (g) nuance, (h) layout, (i) visual weight. Those visual elements formed the main object and background is the main elements that communicate visual self identity of Minangkabau ethnic people in virtual world.

The image contain of visual elements placed in composition of object, background, and color combination or nuance. Image's object has chosen by Minangkabau self to communicate a certain message and purpose. Main reason is to show their proud as Minangkabau ethnic self and their reminiscence of their homeland. Samples of profile picture of Minangkabau self and how it's interpretation show in Table I.

The profile picture is a visual phase of developing ethnic self in virtual world. The profile picture use is chosen individually as representation of Minangkabau ethnic self. It is the individual subjectivity and how they building their ethnic self identity. Subjectivity can be understood from intangible aspects such as self concept, passion, and life value. Self concept is the ideal self form by self appearance, judgment from other, and self feeling. Self concept also built by self judgment from subjective and emotional things. How Minangkabau ethnic self built their self concept also affected by their family value and their intensity to Minangkabau cultural tradition. Self imaginary is a social product. The closeness of self to the family, in the Minangkabau cultural family is especially mother and mother's clan, can affected the forming process of ethnic self. The relation between subjectivity of ethnic self and Minangkabau ethnic visual self identity is explain in Figure 2. 
TABLE I: VISUAL ELEMENTS OF MINANGKABAU IDENTITY IN VIRTUAL WORLD

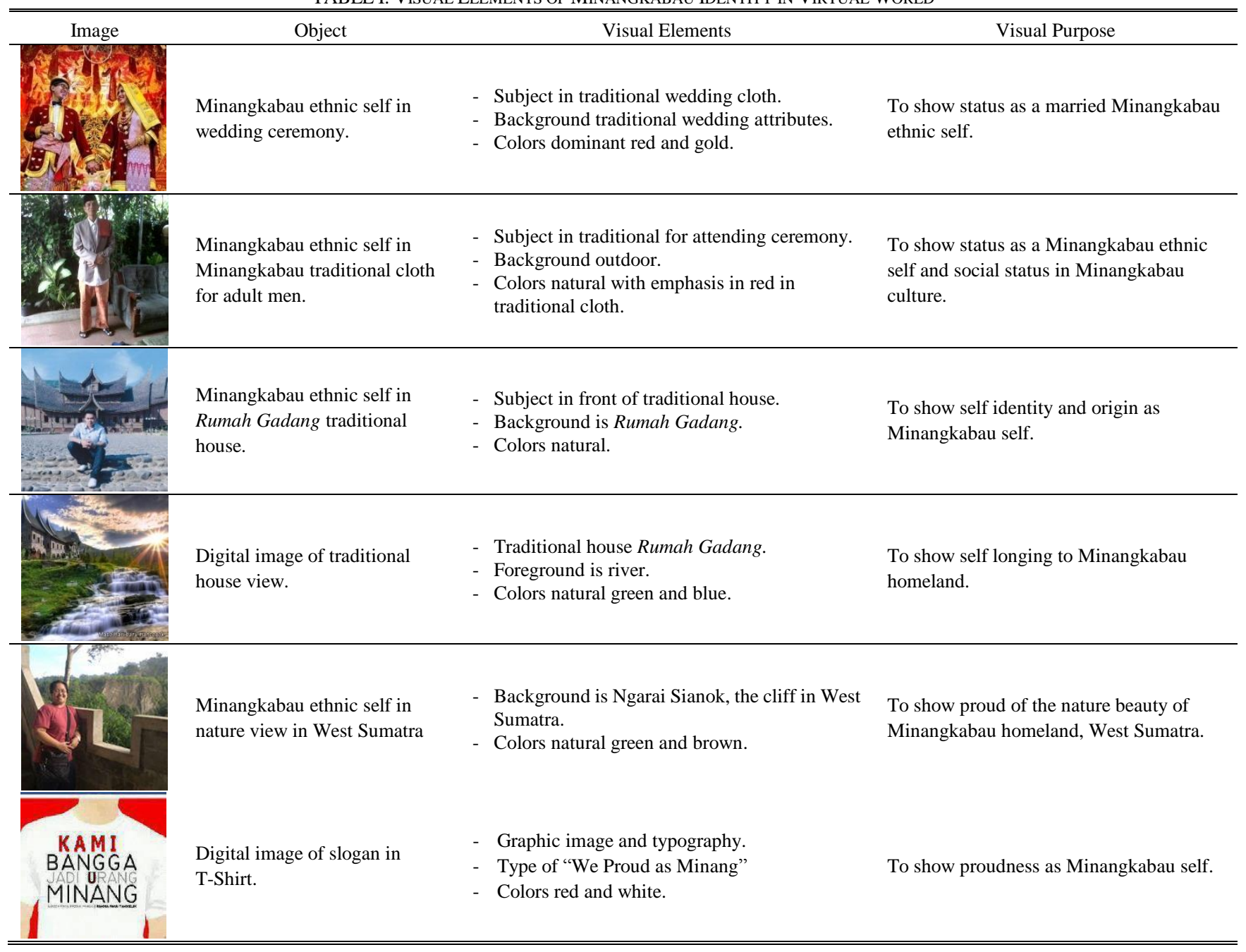

In Fig. 2, the visual phase, subjectivity phase, and cultural phase has represent by rectangular shapes. Visual phase is the first appearance of Minangkabau ethnic self in virtual world. To be able to choose an ethnic self, one has to maintain the subjectivity of oneself as a Minangkabau ethnic self. To become a Minangkabau ethnic self, one has to embrace the Minangkabau ethnic cultural value. The triangle shape represents the Minangkabau ethnic cultural value in their self identity. In their homeland, Minangkabau ethnic cultural value is a central value in everyday life and becoming their main identity. In the migrate land, the cultural value and their subjectivity are in interchange. The self has to blend in the migrate culture but at the same time still hold their identity as Minangkabau ethnic self. In the virtual world, the cultural value is remain in themselves, while the self is blend in no boundaries world of virtual world [9].

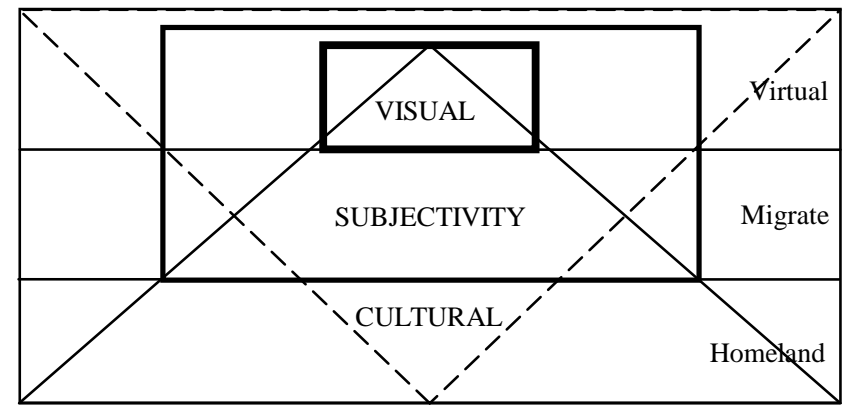

Fig. 2. Subjectivity and Minangkabau ethnic visual self identity.
Minangkabau ethnic self exist in virtual world by valuing six principles of subjectivity and visual identity of Minangkabau which are:

1) Self idealization principle

Minangkabau ethnic self-identity appeared in profile picture as ideal self and imaginary self choose as self representation in virtual world. Profile picture is a main aspect in imagining Minangkabau self. Ideal self visualized into image as their self concept. It promotes the self-concept as Minangkabau ethnic. In virtual world, a second self is a new self, appear as the self imagine to be known and difference from others. The new self is a new experience to Minangkabau ethnic as oneself.

2) Land expanded principle

Minangkabau ethnic people expand their being from homeland to migrate land and to virtual world. The land expanding process is not in a matter of the real being but mainly affected their perceptual. Homeland is where tradition matter in all life aspect individually and socially. Migrate land is where they live with multiethnic society and tradition limited in their own family. While expanding to virtual world, the global cyberspace is becoming their social community where people interact. The ethnic self experiences land expanding process from being in homeland, migrate land, to virtual world.

3) Embeddedness principle

Embeddedness defines as the quality of being firmly and 
deeply ingrained or fix in place [10]. In their homeland, Minangkabau ethnic identity embedded into their life. The daily life affected by traditional norms of Minangkabau. Rules and norms of tradition can't be separated from the personal life and their society. Their life cycle embedded to the traditional process and principle to obey. The culture rules how to perform and what attributes to complete from the born of a child, to grow and married, until the death.

4) Liminality principle

In the migrate land, Minangkabau ethnic identity effected by many external cultural changes. The self is being in the liminality state. In anthropology, liminality means the quality of ambiguity or disorientation in status or stages. The ethnic self built their self concept as ethnic individual affected by tradition and external value. Minangkabau ethnic self is growing in the migrate land while doing the tradition of merantau. Merantau means expanding as Minangkabau self. A person is going outside their homeland to search for better education and better living. As individual, merantau is a personal growth process.

5) Identity personalization principle

In the virtual world, Minangkabau ethnic self built their identity. Virtual world has no limit as global cyberspace. In the broad perceptual space, Minangkabau self built their identity based on the core value of ethnic self. The activity of merantau is not limited to geographical boundaries. Virtual world is the next step of merantau for Minangkabau people. Self identity is fabricated for personal need of individual. Social media is the new cultural society to their user.

6) Ethnic wisdom principle

Minangkabau ethnic identity is being inside personal as a manifestation of life principle and ethnic wisdom of Minangkabau. The principal ethnic wisdom of Minangkabau is Adat Basandi Syarak, Syarak Basandi Kitabullah. It means tradition of Minangkabau based on Islamic law and the Islamic law based on Holy Qur'an. This wisdom is a Minangkabau principle since $19^{\text {th }}$ century and has been declared as cultural identity of Minangkabau. Another ethnic wisdom of Minangkabau is Dima Bumi Dipijak, Di Situ Langik Dijunjuang. It means wherever the Minangkabau ethnic people be is where the sky they uphold. Minangkabau self has to grow in dynamicity wherever they live and respect the people and culture. The wisdom is related to other wisdom, Alam Takambang Jadi Guru. It means nature is the teacher of life. Minangkabau people have to honor the nature as the creation of The Greatness.

\section{CONCLUSION}

Profile picture is a substantial part to define self in virtual world. The online self appeared when the internet is online and the self appear in social media. The subject appearance is a name and image describe in the web. Minangkabau ethnic self marked their existence in virtual world by showing their ethnic self in non boundary society such as cyberspace.
Individual and group profile picture use as samples in research to capture the process of imagining ethnic self in virtual world. Minangkabau ethnic self being in virtual world is the self of imagining. The virtual identity is not necessarily the same as real identity. The ethnic self in real identity are blend in a modern society. But in the virtual world, the ethnic self can identify themselves as they want of being. Building self identity as Minangkabau ethnic self is a continuous process. By valuing six principles of subjectivity and visual identity of Minangkabau, the Minangkabau ethnic self is continuing the process of existing in virtual world. It is the process of developing the incomplete self. Therefore, it is a process of uncertainty. It is mostly the result of imagining self as ideal ethnic self in virtual world.

For further studies, the Minangkabau visual identity principle can be used as a basic principle to design virtual identity of Minangkabau ethnic society in virtual world. Virtual identity of Minangkabau ethnic society can be developed as a media of modern communication or as branding of West Sumatera, Indonesia. The method of this research also can be used in research of visual identity of other ethnic society in virtual world. Virtual ethnography method can be use to research with many ethnic society in cyberspace today.

\section{ACKNOWLEDGMENT}

The author acknowledges the financial support provided by the Faculty of Art and Design, Trisakti University, through the research grant. The author also acknowledges all the research respondents, the member of Palanta Urang Awak Minangkabau in Facebook as the Minangkabau ethnic society in cyberspace.

\section{REFERENCES}

[1] Republic of Indonesia. Country overview. [Online]. Available: http://www.nationsencyclopedia.com/economies/Asia-and-the-Pacific /Indonesia.html

[2] C. Hine, "Virtual Ethnography," Forum Qualitative Social Research, no. 3 , p. $45,2000$.

[3] G. Rose, Visual Methodology: An Introduction to Researching with Visual Materials, London, U.K.: Sage Publication, 2001, pp. 38-46.

[4] M. Ramayulis, Y. Ylizal, and H. Fendi, "ABS - SBK Dalam Masyarakat Minangkabau, Kajian Alat Kelengkapan dan Atribut Adat Dalam Batagak Panghulu," Padang, Indonesia: UPTD Museum Nagari Dinas Budpar Pemprov Sumatera Barat dan Lembaga Penelitian IAIN Imam Bonjol, p. 43.

[5] M. Naim, Merantau, Pola Migrasi Suku Minangkabau, 3rd ed. Jakarta, Indonesia: Rajawali Pers, 2013, p. 13.

[6] S. Turkle, "Life on the screen", Cambridge Mass Massachusetts Institute of Technology Center for International Studies, p. 9, 1995.

[7] R. Nasrullah, Komunikasi Antarbudaya, Di Era Budaya Siber, Jakarta, Indonesia: Kencana Prenada Media Group, 2012, pp. 129.

[8] U. P. Autenrieth and K. Neumann-Braun, The Visual Worlds of Social Network Sites, Deutchland: Nomos, 2011, pp. 19

[9] E. Franzia and Y.A. Piliang, "The Sustainability of Minangkabau ethnic identity philosophy in virtual community Palanta UrangAwak Minangkabau," in Proc. the 3rd International Conference on Nusantara Philosophy, 2015, pp. 189-199.

[10] [Online]. Available: http://en.oxforddictionaries.com

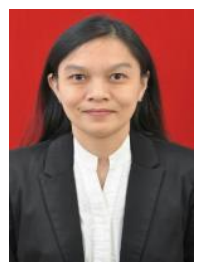

Elda Franzia was born in Paris, on May 7th 1973. The author's educational background is bachelors degree of visual communication design at Trisakti University, Jakarta, Indonesia in 1997, master degree of design studies at Trisakti University, Jakarta, Indonesia in 2009 , and doctoral degree of art and design science in Institute Technology of Bandung, Indonesia in 2016. 
She works as a lecturer of bachelors degree and master degree in Faculty of Art and Design, Trisakti University, Jakarta, Indonesia. Current position is head of Visual Communication Design Program at Faculty of Art and Design, Trisakti University. Previous research on virtual identity of Minangkabau ethnic society in social media published on Mediterranean Journal of Social Science Vol 8, 2017; International Journal of Social Science and Humanity, Vol. 5 No. 1, 2015; and proceeding of the 3rd International Conference on Nusantara Philosophy, University of Gadjah
Mada, Indonesia, 2015. Current research interest is virtual identity in socia media communication.

Dr. Franzia is a member of Association of Indonesian Graphic Design (ADGI) and Association of Indonesian Lecturer (ADI). She is also an active member of Association of Indonesian Visual Communication Design Program and Coordinator of Association of Visual Communication Design Program - Jakarta Chapter. 